\title{
Proceeding
}

Supplementary Issue: Spring Conferences of Sports Science. First International Conference in Iraq on Sport for Peace, 4 April 2019. Baghdad Science Institute, Baghdad, Iraq.

\section{The relationship of sports flannel on skin contact allergy, white blood cells and distance achievement of weight-throwing players}

\author{
ALI AHMED ALAWADY \\ University of Al-Qadisiyah, Iraq
}

\begin{abstract}
This study aims at identifying the relationship of sports flannel on skin contact allergy, white blood cells and distance achievement of weight throwing players from the colleges of the University of Al-Qadisiyah. The descriptive approach was used in a correlative style due to its suitability with the nature of the study. The sample of the study consists of 18 players, one player of each college of the University of Al-Qadisiyah. The players are divided into two groups with equal numbers (the first group players wear flannel made of natural fabric while the second group players wear flannel made of nylon). Then, the flannel fabric tested for the stretch and tightening test in a specialized laboratory on the first of March 2018. The researcher requested from the players, in accordance with the consultation of dermatologist to wear the flannel in its both types after the pre-test for both groups for three days. The test includes the blood test, height, weight and distance of throwing. The test lasted till $6 / 3$ and the patch test placed. Posttest took place on $7 / 3,9 a$.m at the University of Al-Qadisiyah, College of Physical Education Stadium. The researcher used statistically questions to deal with the raw data. The study findings showed that there are differences of statistical and health significance of skin allergy, increase of white blood cells and distance achieving for both groups and in favour for the first group except three players from the second group whom do not affected by skin contact allergy. Keywords: Flannel; Contact allergy; White blood cells; Distance achievement.
\end{abstract}

\section{Cite this article as:}

Alawady, A.A. (2019). The relationship of sports flannel on skin contact allergy, white blood cells and distance achievement of weight-throwing players. Journal of Human Sport and Exercise, 14(4proc), S442-S449. doi:https://doi.org/10.14198/jhse.2019.14.Proc4.02

Corresponding author. University of Al-Qadisiyah, Iraq.

E-mail: alialawady@gmail.com

Supplementary Issue: Spring Conferences of Sports Science. First International Conference in Iraq on Sport for Peace, 4 April 2019. Baghdad Science Institute, Baghdad, Iraq.

JOURNAL OF HUMAN SPORT \& EXERCISE ISSN 1988-5202

(c) Faculty of Education. University of Alicante

doi:10.14198/jhse.2019.14.Proc4.02

S442 | 2019 | Proc4 | VOLUME 14

(C) 2019 University of Alicante 


\section{INTRODUCTION}

Among the distinguishing features of technology is to use diverse techniques that are suitable for the athletics activities, and contributes to develop it but it sometimes unhealthy and reduces the athletics achievement. Because some companies unscientifically manipulated the structure of fabric and dresses, which affects the physiological functions through the relationship with geographical environment and misbalances of body temperature and climate one. Also, to ensure the stability of appropriate temperature for the player's organs despite the differences of surrounding circumstances (Maberry, 2007). In order to ensure the transfers of temperature and humidity and get rid of it depends on the air gaps and fabric contents. The flannel must be fit for the environmental changes and expels humidity of the body without feeling wet. If it is unable to get rid of it, the sense of unrest will result. (Amar \& El-Okeily 1998). Nylon threads regarded as an excellent insulating one since it has electrostatic properties in comparison with other threads because of its inability to absorb humidity. This trait has disadvantages as accumulation of electrostatic charges on fabrics and threads in addition to its getting dirty in a dusty weather. (Naser \& Alzugbi 2005). The phenomena of continuous contact of the sport flannel during the exercise and playing leads to the appearance of allergy of skin contact to athletics due to the little air going through the micron gaps in flannel. It also prevents evaporation of sweat, which does not lead to the feeling of cold, eventually leads to reduce the achievements in the distance of weight throwing. The importance of the study considered one of several studies, which deals with wearing sport flannel of the student's athletics and its effects on the skin contact allegory, white blood cells and distance dis-achieving.

\section{THE RESEARCH PROBLEM}

The research problems is the necessity of revelling the common relations between the players of weight throwing and wearing sport flannels made of natural and artificial fabric, the kind of thread, air access, sweating and generating of electro charges due to continuous contact with the athletics students skins during warming up and playing. Moreover, it results to the emergence of allergic reactions with the increase of white blood cells as a defending phenomenon to most of the players who wear nylon fabric. Due to the rareness of the studies in this field, the researcher adopts the research to solve the problem.

\section{THE STUDY OBJECTIVES}

The study aims at identifying the relationship between wearing flannels for athletics and the skin contact allergy, white blood cells and distance achievement to University of Al-Qadisiyah weight throwing players.

\section{HYPOTHESIS}

There are differences statistical significance between the first and second groups in favour of the first group in distance achievement due to contact allergy, white blood cells for the players of the colleges of AlQadisiyah university in weight throwing.

\section{STUDY LIMITATIONS}

Human: players of the colleges of the university of Al-Qadisiyah in weight throwing.

Place: stadium of the college of Physical Education and Department of Chemistry Laboratory at the University of Al-Qadisiyah.

Time: $1-7 / 3 / 2018$ 


\section{THE STUDY APPROACH}

The descriptive approach was used in correlative and experimental method because it is suitable to the nature of the study.

\section{THE STUDY POPULATION AND SAMPLE}

The sample includes 18 athletics students who play weight throwing from the colleges of the university of AlQadisiyah. Their agreement has been gained previously about the study. The sample divided into two groups with equal numbers.

\section{EQUIPMENT AND DEVICES}

The device of measuring stretching and tightening strength, (Laree technology co. Itd2013) is used in room temperature with load of $20 \mathrm{KN}$ and the speed cut was $2005-\mathrm{mm} /$ minute. The property of tightening is to know the flexibility factor, tightening strength and stretching.

Weight and height measurement device, Japanese origin, 2017, 2 devices, measuring tape50 meter, weight $7 g, 2$ devices.

Blood analyser and data application for results of tests for both groups attached in appendix (1).

Metal plates made of aluminium foils, allergic materials with light concentration and adhesive tapes.

Athletics flannel made of (natural fabric - artificial - nylon threads).

\section{Exploratory Experiment}

To ensure the accuracy and validity of the devices, the researcher conducted an experiment on four students on 5/3/2018 9 a.m., distributed on two groups, two for each group at the college of Physical Education Stadium.

\section{The tests}

- $\quad$ The test of stretching and tightening on flannel with (natural and artificial threads) has been fulfilled on $1 / 3 / 2018$, 8a.m.

- $\quad$ The height and weight taken on 1/3, 8:30a.m. The sample of blood was taken for both groups to test the white blood cells. Then immediately the test of weight throwing was performed to measure the distance with three attempts for each player of both groups.

- $\quad$ According to the working assisting team (skin disease consultants) the researcher requested from both groups players to wear the flannel with natural and artificial made in the exercise of the period 2$7 / 3 / 2018$.

The researcher examined the Patch test at the morning of 2/7/2018 at 9a.m for both groups using metal plates made of aluminium placing the allergic materials on them. The allergic materials have been attached with an adhesive tape on the back of players for 48 hours then removed and measured after 30 minutes and measured again after 72 hours. Allergic symptoms appeared on six players out of nine of the second group through redness and itching that are observed by the assistant working team specialized in skin diseases, before performing the distance tests.

- $\quad$ The blood sample was taken on 7/3 then the weight throwing performed. 
The researcher and the consultant medical team of skin disease observed allergy symptoms appeared on six players of the second group in the form of pimples, redness and itching during the exercise.

Table 1. Tress (MpaSTRAIN (\%) stress spoot (Test yarns (natural and nylon) - strain curve.

\begin{tabular}{|l|l|l|l|}
\hline CUSTOMER & SPOOT & TESTDATE & $1 / 3 / 2018$ \\
\hline COIL NO / PACKET NO & & Type & FLAT* \\
\hline SIZE ( MM( & $\begin{array}{l}1 * 2 \\
1 * 2\end{array}$ & SO )MM2***( & 2.00 \\
\hline LO (MM**** & 15 & 1 & \\
\hline $\begin{array}{l}\text { FM ( KN****( } \\
\text { Result of the first set }\end{array}$ & 2.187 & RM )Mpa( & 1094 \\
\hline Result of the second set & 0.0012 & RM )Mpa( & 1 \\
\hline
\end{tabular}

Table 2. The equivalence between both study groups, The results of Mann Whitney test of equivalent research groups in age, weight, and length (separately)

\begin{tabular}{|c|c|c|c|c|c|c|c|}
\hline Variable & groups & No & $\begin{array}{l}\text { Mean } \\
\text { rank }\end{array}$ & $\begin{array}{l}\text { Ranks } \\
\text { sum }\end{array}$ & $\begin{array}{l}\text { Mann Whitney } \\
\text { counted Value }\end{array}$ & $\begin{array}{l}\text { significance } \\
\text { level of } 0.05\end{array}$ & Decision \\
\hline Age & First & 9 & 9.50 & 85.50 & \multirow{2}{*}{40.5} & \multirow{2}{*}{ insignificant } & \multirow{8}{*}{ equivalent } \\
\hline & Second & 9 & 9 & 85.50 & & & \\
\hline Weight & First & 9 & 9.94 & 89.5 & \multirow{2}{*}{36.5} & \multirow{2}{*}{ insignificant } & \\
\hline & Second & 9 & 9.06 & 81.50 & & & \\
\hline Length & First & 9 & 9.17 & 82.50 & \multirow{2}{*}{37.5} & \multirow{2}{*}{ insignificant } & \\
\hline & Second & 9 & 9.83 & 88.5 & & & \\
\hline \multirow[t]{2}{*}{$\begin{array}{l}\text { White blood } \\
\text { cells }\end{array}$} & First & 9 & 8.78 & 79.00 & 34.00 & insignificant & \\
\hline & Second & 9 & 10.22 & 92.00 & & & \\
\hline
\end{tabular}

\section{Statistical means}

The mean, standard deviation, T. test for correlative samples.

\section{DISCUSSION}

Since we have two independent groups, in each group there are repetitions of the (inflicted - not inflicted) so chi-squared for independency is used to measure the difference between the groups as shown in table (3) below.

Table 3. Presents the infliction repetition between the groups

\begin{tabular}{|c|c|c|c|}
\hline Group & Good & Infected & Total \\
\hline First & 9 & 0 & 9 \\
\hline Second & 3 & 6 & 9 \\
\hline Total & 12 & 6 & 18 \\
\hline
\end{tabular}

After performing chi-squared test of independence, it showed that the calculated value was (10), which is higher than the tabular value at significance level (0.05) and free degree (1) reached (3.84). It shows there are differences between the two groups in favour for the first group. The results can be explained that the 
flannel types showed infection cases from nylon flannel. The total number of the second group was 9; six of them were infected while three did not. The researcher explains that this disinfection due to their immunity and their resistance to allergy because it is different from one person to another due to the ability of adaption.

Table 4. Results of the average of throws of the study groups (before and after)

\begin{tabular}{|c|c|c|c|c|c|c|}
\hline Group & Flannel type & No. & Group case & $\begin{array}{c}\text { *average of weight throwing } \\
\text { distance }\end{array}$ & & \\
\hline & & & & before & After & \\
\hline First & Natural fabric & 9 & Healthy & 10 & 10.7 & \\
\hline Second & Nylon & 3 & Healthy & 9.8 & 10 & $7.90 \uparrow$ \\
\hline & Nylon & 6 & Allegoric & 5.80 & \\
\hline Total & & 18 & & & 15.8 & \\
\hline \multicolumn{7}{|c|}{ *average of three throws\& distance by meter. }
\end{tabular}

Table (4) indicates that the average of weight throws showed a clear difference between the two groups in favour of the first group in comparison between the pretest and posttests and between the groups. The first group recorded in pretest $(10 \mathrm{~m})$ while in the posttest is $(10.75 \mathrm{~m})$. The second group has achieved in the pretest $(9.80 \mathrm{~m})$ and in the posttest $(7.90 \mathrm{~m})$. It shows decrease due to the infection of (6) players, which recorded $(5.80 \mathrm{~m})$ and the $(3)$ healthy players recoded $(10 \mathrm{~m})$ that affected on the throwing distance average of the second group. The researcher interprets this case due to the types of the flannel used as showed in table (1) that is measuring the stretching, tightening and the length of the cut area of the flannel threads in respect to flexibility aspect. The difference was great between the two groups in respect to the textile structure aspect, which has a vital role in air access and the physiological relationship with the body which referred to by (Badr, 2012) in reducing the percentage of humidity and change in dimensions. And this claim supports the researcher's interpretation that the continuous contact with less wet absorption and no air access inside and outside because of the threads lines rows and columns. The continuous contact caused a skin contact allergy because of the mechanical and physical properties of the types of nylon threads which do not absorb humidity.

Table 5. Mann-White ny $U$ test results of the significant differences in the variable of white blood cells for the two groups

\begin{tabular}{|c|c|c|c|c|c|c|}
\hline The Variable & Group & No. & $\begin{array}{c}\text { Mean } \\
\text { Rank }\end{array}$ & $\begin{array}{c}\text { Sum of } \\
\text { Ranks }\end{array}$ & $\begin{array}{c}\text { The accounted } \\
\text { value }\end{array}$ & $\begin{array}{c}\text { Indicator at a level } \\
\text { of } \mathbf{0 . 0 5}\end{array}$ \\
\hline $\begin{array}{c}\text { White blood } \\
\text { cells }\end{array}$ & First & 9 & 5.22 & 47.00 & 2.00 & Mark \\
\hline & Second & 9 & 13.78 & 124.00 & & \\
\hline
\end{tabular}

Table (5) results showed that there is a statistical significance of white blood cells in comparison the first group with the second group. The medical interpretation showed an increase number of white blood cells as a defiance mechanism against illness or body infection. The researcher explains that the skin contact allergy of (6) infected individuals of the second group shows an increase in defendant cells because of the piling of static electro-waves on the lines and hairs during the movement. Also, it hinders the movement of the athletic students. This is what (Song, 2011) has referred to that the comfort of the body inside the clothes, which provide the protection and individual realization. (Zora, 2017) sees that one of the methods of protecting human body against extra-temperature load through organizing temperature by sweating. The researcher indicates that it has a relationship with the properties of the manufactured threads of the fabric. The study 
supported by (Mohammad \& Ghalib, 2014 reported by SamiaLatfy 1997) who stated and agreed that the clothes should do the role of what they want from the aspect of comfort and free movement.

Table 6. The differences of distance achievement of weight throwing for the two groups before and after the contact allergy

\begin{tabular}{|c|c|c|c|c|c|}
\hline \multicolumn{2}{|c|}{$\begin{array}{c}\text { The average of throwing weight } \\
\text { throwing of the players who wear a } \\
\text { natural flannel }\end{array}$} & \multicolumn{2}{|c|}{$\begin{array}{l}\text { The average of throwing weight } \\
\text { throwing of the players who wear } \\
\text { nylon flannel }\end{array}$} & \multicolumn{2}{|c|}{$\begin{array}{c}\text { Difference of } \\
\text { Distance of weight } \\
\text { throwing }\end{array}$} \\
\hline $\begin{array}{l}\text { Before } 5 \text { days of } \\
\text { wearing the } \\
\text { flannel }\end{array}$ & $\begin{array}{l}\text { After } 5 \text { days of } \\
\text { wearing the } \\
\text { flannel }\end{array}$ & $\begin{array}{l}\text { Before } 5 \text { days of } \\
\text { wearing the } \\
\text { flannel }\end{array}$ & $\begin{array}{l}\text { After } 5 \text { days of } \\
\text { wearing the } \\
\text { flannel }\end{array}$ & $\begin{array}{c}\text { Before the } \\
\text { test }\end{array}$ & $\begin{array}{c}\text { After the } \\
\text { test }\end{array}$ \\
\hline First group & & Second group & & $\# 20$ & $\& 1.90$ \\
\hline 10 & 10.75 & 9.80 & 7.80 & & \\
\hline
\end{tabular}

Table (6) indicates that the difference of weight distance between pretest of the first group was $(20 \mathrm{~cm})$ while there is a huge difference of the posttest $(1.90 \mathrm{~m})$. The researcher explains this great difference of results in which two researchers (KátiaSheylla \& Leite, 2014) where repetition of effect, contact of skin with clothes, humidity, skin limited ventilation affected on the average of distance achievement. The continuous and direct exposure to sunlight especially UV in Iraqi weather and the continuous contact between the type of flannel and the players skin generate electro charges as well as the dust, accumulative sweat lead to the appearance of some cases for skin contact disease that cause slow itching and pimples. The consultant medical team observed this before the posttest in which they were basically wearing the sport flannel made from nylon before 6 days. The study agreed in some results that the nature of weather and contact during competition with the study of (Yosipovitch \& De Luca, 2012) and (Aman ${ }^{* *} \&$ Kazmi \& Shaukat $\left.{ }^{*}, 2015\right)$. This supports the study in its claim that the second group was unable to achieve weight throwing who wear nylon flannel because of allergy, itching and pimples on their skins. Before wearing flannels, this group achieved a distance of $9.80 \mathrm{~m}$ in weight throwing in the first test while they achieve $5.80 \mathrm{~m}$ when they wear the flannels. That is why the results of the six allergic players out of nine get down to. While the other healthy three players from the same group achieved the first test $9.80 \mathrm{~m}$ and the second one is $10 \mathrm{~m}$. By comparing this does not consider as an achievement because it is not ambitious. The researcher thinks if the period lasted longer, the symptoms of contact allergy will appear because of their bodies and skins resistance because of white blood cells as the researcher depended on the skin disease consultants team.

\section{CONCLUSIONS}

The researcher finds out the followings:

- Wearing sport flannel made of nylon threads has a direct effect on the skin allergy because of the stretching and tightening of threads and continuous contact which resulted in continuous electro charges, no air ventilation, sweat and dust.

- Wearing of sport flannel made of nylon threads has a direct effect on the level of achieving due to the movement of huge numbers of white blood cells inside the body as a defendant mechanism against illness and infections because of the continuous itching and the appearance of red skin pimple, which affect the level of distance achievement. 


\section{RECOMMENDATIONS}

In the light of the findings which reached by this study, the researcher recommends the following:

- Repeating the study, in an experimental program for 8 weeks with the variety of wearing sport flannel made of (wool, cotton, nylon, natural plastic and flannel mixed partly from natural and artificial materials).

\section{REFERENCES}

Badr A., Elokeily M. and Farag R.(2012)."Performance of natural cellulosic fibers and regenerated cellulosic fibers in physiological comfort of knitted fabric", faculty of Engineering, Mansoura University, March.

De Luca, J. F., Adams, B. B., \& Yosipovitch, G. (2012). Skin manifestations of athletes competing in the summer Olympics. Sports Medicine, 42(5), 399-413. https://doi.org/10.2165/11599050-00000000000000

Guowen Song. (2011). "study on improving comfort in clothing", University of Alberta, Canada, Wood head publishing Series in Textiles No. 106.

Ismail, M. I., Ammar, A. S. A., \& El-Okeily, M. (1988). Heat transfer through textile fabrics: mathematical model. Applied mathematical modelling, 12(4), 434-440. https://doi.org/10.1016/0307904x(88)90075-3

Maberry, S.I. (2007). (ED.), Healthcare Design, John Willey \& son.,U.S.A.

Mohammad, I.I. and Ghalib, M.M.(2014). The Effect of Some Mechanical Physical Properities of Altreco Clothing on Comfort. Alex. J. Agric. Res. Vol. 59, No. 3, pp. 3179.

Nasar, A. and Alzukbi, K. (2005). Studies in Textile, Dar AlfikrAlarabi, Cairo, p38.

Purim, K. S. M., \& Leite, N. (2014). Sports-related dermatoses among road runners in Southern Brazil. Anais brasileiros de dermatologia, 89(4), 587-592. https://doi.org/10.1590/abd1806-4841.20142792

ShehlaShaukat, ShahbazAman, Atif H. Kazmi. (2015).Skin and sports. Journal of Pakistan Association of Dermatologists. 25 (3):206-211.

Zhiwei Li*, Yong Wang,(2018 ) Study on the effect of professional sports clothing on sports physiology,Biomedical Research,1Department of Physical Education, Hunan University of Commerce, PR China 2Department of Immunology, School of Basic Medical Science, Xiangya School of Medicine, Central South University, PR China. https://doi.org/10.17140/doj-2-112

Zora, S., Balci, G., Colakoglu, M., \& Basaran, T. (2017). Associations between thermal and physiological responses of human body during exercise. Sports, 5(4), 97. https://doi.org/10.3390/sports5040097 


\section{APPENDIX}

Appendix 1. A sample of data form and distance achievement and skin allergy for the two groups starting from 1-9 for each group

\begin{tabular}{|c|c|l|l|l|c|l|l|l|l|l|l|l|}
\hline $\begin{array}{c}\text { Group } \\
\text { name }\end{array}$ & No. & Age & Weight & Height & $\begin{array}{c}\text { Data of } \\
\text { throwing in } \\
\text { accordance } \\
\text { of numbers } \\
\text { of turns in } \\
\text { meters }\end{array}$ & & & & & & & \\
\hline First turn & & $\begin{array}{c}\text { Second } \\
\text { blood } \\
\text { cells }\end{array}$ \\
\hline $\begin{array}{l}\text { First or } \\
\text { second }\end{array}$ & $1-91-91$ & & & & Before & After & Before & After & Before & After & Before & After \\
\hline
\end{tabular}

Appendix 2. Assisting working team

\begin{tabular}{|c|c|c|c|c|c|}
\hline No. & $\begin{array}{c}\text { Assisting group } \\
\text { name }\end{array}$ & No. & Full name & Place of work & Specialization \\
\hline \multirow[t]{2}{*}{1} & $\begin{array}{l}\text { Test of sport flannel } \\
\text { (natural/artificial) }\end{array}$ & 1 & $\begin{array}{l}\text { Prof.Mohammad Ali } \\
\text { Alwaali (PhD) }\end{array}$ & $\begin{array}{l}\text { University of Al-Qadisiyah - } \\
\text { College of Engineering }\end{array}$ & Polymer \\
\hline & & 2 & QusayHasanAlshamsi & $\begin{array}{c}\text { Baghdad- } \\
\text { AlsadrAlthaneaaDirectorate of } \\
\text { Education }\end{array}$ & Polymer \\
\hline \multirow[t]{2}{*}{2} & $\begin{array}{l}\text { Referee of weight } \\
\text { throwing }\end{array}$ & 1 & $\begin{array}{c}\text { Prof. Raheem } \\
\text { RuwahHabeeb(PhD) }\end{array}$ & $\begin{array}{l}\text { University of Al-Qadisiyah- } \\
\text { College of Physical Education }\end{array}$ & $\begin{array}{l}\text { International } \\
\text { referee/ field and } \\
\text { truck }\end{array}$ \\
\hline & & 2 & SubahiAbduljaleel & Athletics federation & $\begin{array}{l}\text { Federal referee - } \\
\text { weight throwing }\end{array}$ \\
\hline \multirow[t]{2}{*}{3} & dermatologist & $1-$ & $\begin{array}{c}\text { Assistant Prof. } \\
\text { AsuamaAlthewani }(\mathrm{PhD})\end{array}$ & $\begin{array}{l}\text { University of Al-Qadisiyah - } \\
\text { College of Medicine }\end{array}$ & dermatologist \\
\hline & & 2 & Dr. Samera Mahdi Abood & \multirow{2}{*}{$\begin{array}{c}\text { Ad Diwaniyah Educational } \\
\text { Hospital }\end{array}$} & dermatologist \\
\hline 4 & Blood test & 1 & FahimHashim Mohammad & & Disease test \\
\hline
\end{tabular}

\section{(c) (i)(9)}

This work is licensed under a Attribution-NonCommercial-NoDerivatives 4.0 International (CC BY-NC-ND 4.0). 